\title{
THE CARBONATITES OF AMBA DONGAR, GUJARAT, INDIA
}

\author{
S. G. VILADKAR
}

\begin{abstract}
VILADKAR, S. G. 1981: The carbonatites of Amba Dongar, Gujarat, India. Bull. Geol. Soc. Finland 53-1, 17-28.

The geology, petrography and major and trace element geochemistry of Amba Dongar carbonatites are described. The ring structure of Amba Dongar carbonatite-alkalic complex has a central core of basalt collared by carbonatite breccia which in turn is surrounded by a sovite rim. Ankeritic carbonatite occurs as disjointed plugs intruding sovite and also as small dikes in surrounding sovite, fenites and basalts. Sideritic carbonatite forms thin veins in ankeritic carbonatite. Plugs of nephelinite and phonolitic nephelinite form the outermost ring of the complex. The complex is intrusive into Bagh sandstone-Deccan Traps sequence (Cretaceous-Eocene) and is situated in the rift zone of Narmada valley. The trace element contents reveal certain characteristic features such as pronounced enrichment in $\mathrm{Ce}+\mathrm{La}(>3.0 \%)$ in ankeritic carbonatite and high values of $\mathrm{Th}, \mathrm{Ba}$ and $\mathrm{P}$. Fenitization of surrounding Bagh sandstone shows two distinct trends: 1. earlier soda fenitization (orthoclase-albiteaegirine rock) and 2. potash fenitization leading to the development of pure feldspar rocks. The paper describes briefly the fenitization of nephelinites for the first time.
\end{abstract}

S. G. Viladkar, Geology Department, St. Xavier's College, Bombay.1

\section{Introduction}

The Amba Dongar carbonatite-alkalic complex is a classic example of ring structure with an innermost ring of carbonatite breccia rimmed by sovite while ankeritic carbonatite forms plugs intruding the sovite. The central depression is occupied by intrusive tholeiitic basalt which came towards the end of carbonatite activity invading the original core of carbonatite breccia, the remnants of which are, in places, seen as xenoliths within the former. Carbonatite breccia also forms a discontinuous outer rim to sovite. Plugs of nephelinite and phonolitic nephelinite mark the outer limit of the ring structure. The complex is a part of the Chhota Udaipur carbonatite-alkalic district which covers an area of about $1200 \mathrm{~km}^{2}$ and includes three major complexes: 1 . The Amba Dongar car-

1 Present address: Mineralogisches Institut der Universität Freiburg, West Germany bonatite-alkalic ring complex, 2 . the carbonatite-alkalic complex of Panwad-Kawant and 3 . the large $(11 \mathrm{~km})$ carbonatite breccia sill at Siriwasan. The dating done so far gives three very different ages; $37.5 \pm 2.5$ ma (Deans and Powell 1968), $61 \pm 2$ ma and $76 \pm 2$ ma (Deans et al, 1973). Precise dating is still awaited.

Pronounced effects of fenitization on surrounding sandstone were described earlier by Deans et al. $(1972,1973)$ and Sukheswala and Viladkar (in press). The basic rocks (pre-carbonatite basalts and dolerite dikes) have also undergone $\mathrm{CO}_{2}$ and alkali fenitization (Sukheswala et al., in press). Recent work shows that nephelinites associated with and enveloped in sovite have been affected by the fenitizing fluids from the carbonatite magma.

Large reserves of fluorite deposits, estimated by the Geological Survey of India as 


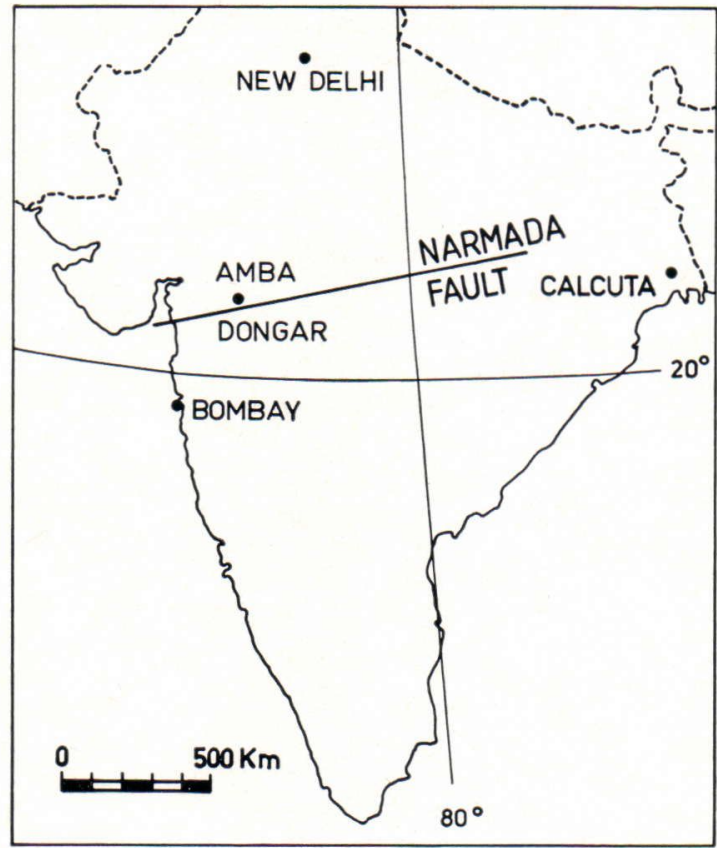

Fig. 1. Map of India, showing the site of Amba Dongar and the Narmada-Son lineament.

11600000 tons averaging 30 per cent $\mathrm{CaF}_{2}$, are associated with the carbonatites and are presently mined by the Gujarat Mineral Development Corporation. Fluorite veins and replacement deposits occur both in sovite and ankeritic carbonatites. Minerals associated with fluorite are barite, galena, pyrite, chalcopyrite and dickite.

The earlier published work on the complex includes the papers by Sukheswala and Udas (1963, 64, 67), Deans and Powell (1968), Sethna (1971) and Deans et al. (1972, 73).

\section{Structural characteristics}

The complex is situated within the rift zone of Narmada river trending ENE, which lies about $9 \mathrm{kms}$ to the south of the complex (Fig. 1), and has a sympathetic fault system in the north of the complex. The main structural feature of the complex is updoming of the Bagh sandstone-limestone and overlying basalts. As a result the Bagh sandstones around the sovite ring dike show radial outward dips of high angles (Fig. 2). The tectonic effects of the complex can well be observed up to the periphery of $5 \mathrm{~km}$ as the sandstone outcrops and basalts in the surrounding region are highly disturbed, faulted and show slumping. During updoming multitudes of fractures and joints created in the surrounding sandstone acted as channeways for the fenitizing solutions. Radial to the dome run several valleys and geological mapping reveals the faulted nature of some of the major valleys. Postcarbonatite fault movements were mainly responsible for the formation of steep vertical scarps exposing sovite and carbonatite breccia. Of particular interest is a vertical scarp of $80 \mathrm{~m}$ in the eastern part of the sovite ring dike. The sovite outcrop in this section shows major slumping (Fig. 3). A network of alvikite dikes is seen at the base of this scarp. Most of the fault valleys are occupied by thick travertine deposits.

The sovite and fenites exhibit intense fracturing and micro-faulting. The thin dikes of alvikite and ankeritic carbonatite show displacements. In fluorite mines, sections of sovite exposed during mining operations reveal fracturing and abundant brecciation. These fracture planes served as channels for ankeritic melts, resulting in criss-cross veining, and also for hydrothermal solutions carrying fluorine and abundant silica.

\section{Carbonatites}

Seven units of carbonatites are discernible in the complex:

1. Carbonatite breccia forming an inner and outer rim to sovite and also occurring as separate plugs in surrounding sandstone and basalt.

2. Sovite forming a large ring dike and isolated plugs in surrounding sandstone. 


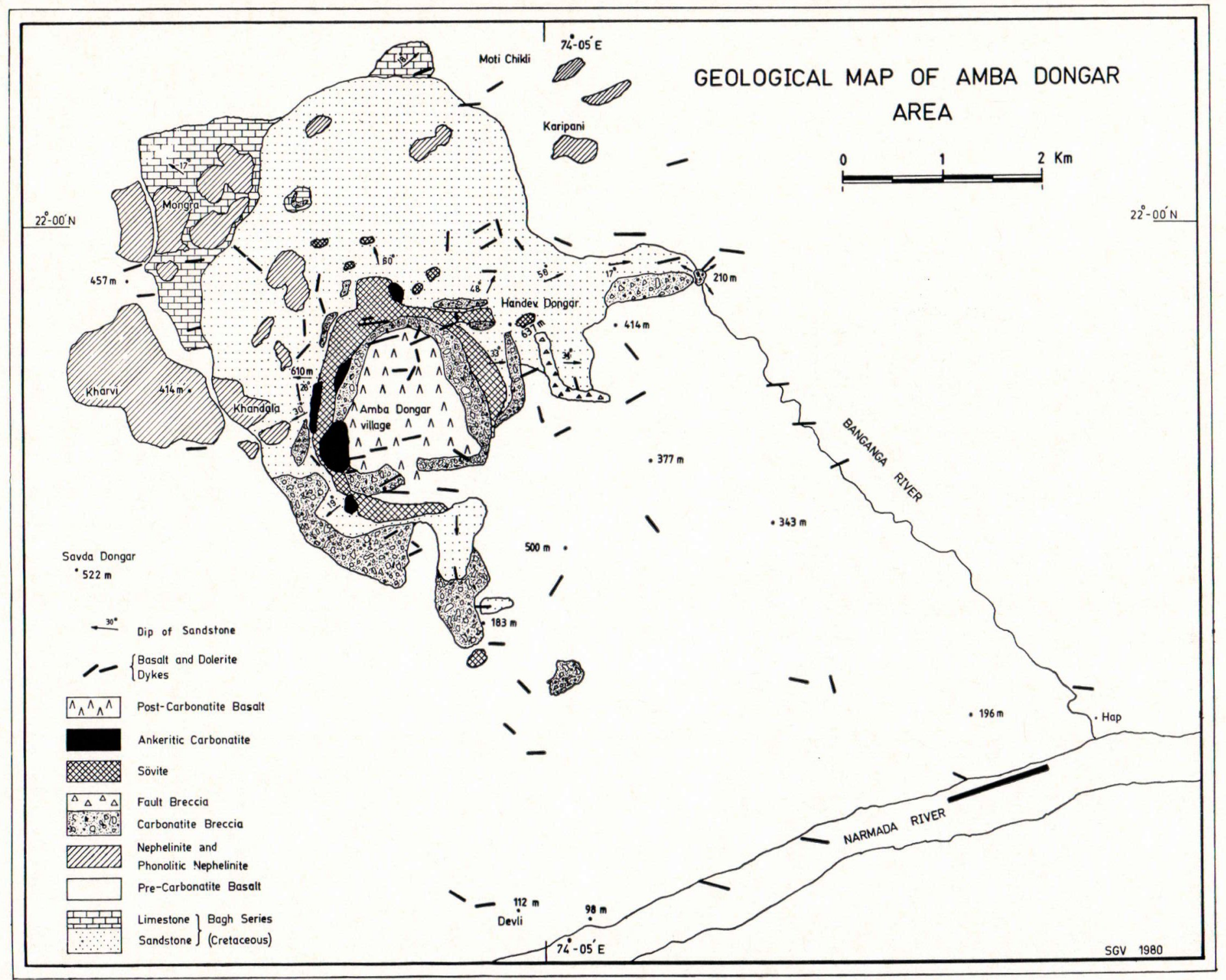




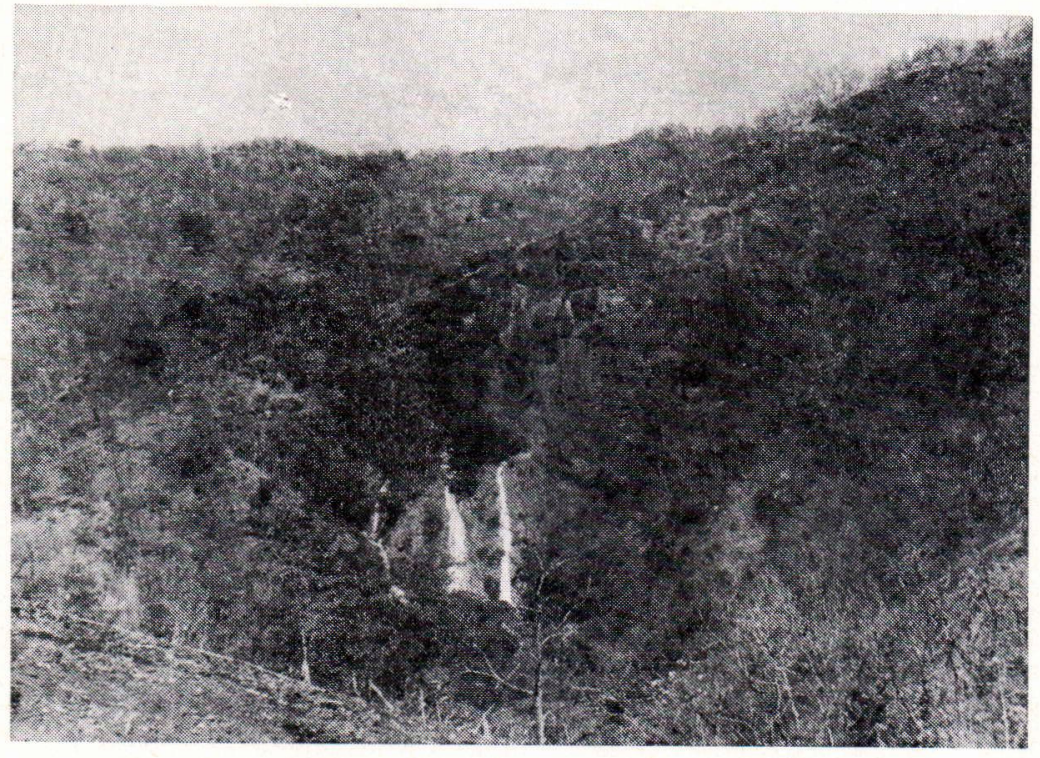

Fig. 3. Vertical scarp in the eastern part of sovite ring dyke. At the base of the scarp is a network of alvikites.

3. Ankeritic carbonatite occurring as plugs within sovite and veins in sandstone, basalt, fenite and sovite.

4. Sideritic carbonatite invading ankeritic carbonatite.

5. Alvikite invading sovite, fenite, carbonatite breccia and sandstone.

6. Silicified carbonatite.

7. Pegmatitic carbonatite invading sovite.

\section{Carbonatite breccia}

The carbonatite activity in Amba Dongar began with the emplacement of a plug of carbonatite breccia of about $1.5 \mathrm{~km}$ in diameter which, towards the end of carbonatite activity, was intruded by multiple injections of basalts and is now seen only as a major rim around the central core of basalt. Besides this innermost rim carbonatite breccia also forms a discontinuous outer rim to sovite and circular and oblong-shaped outcrops in the surrounding Bagh sandstone and basalt. Major outcrops of this rock are seen in the valleys as steep escarpments of about 200 metres. Huge boulders measuring $10 \mathrm{~m} \times 6 \mathrm{~m}$ are quite common. The rounded to subangular fragments in breccia show great variation in size from a few $\mathrm{cm}$ up to $1 \mathrm{~m} \times 1 / 2 \mathrm{~m}$. Sovite constitutes the major proportion of the rounded fragments, the others include metamorphics, sandstone, basalt, and nephelinite all set in a calcitic or ankeritic matrix.

Xenocrystal quartz, probably from the metamorphics, is abundant and is partly converted to orthoclase. Differential weathering of the enclosed fragments gives the rock an appearance simulating vesicular rock, because the sovite fragments being weathered easily are removed and rims of harder matrix stand out prominently. Very often rounded fragments of sovite are liberated from the matrix and are dispersed in the soil. The carbonatite breccia has been intruded by alvikite, ankeritic carbonatite and a number of dolerite dikes.

\section{Sovite}

Sovite forms a large ring dike of variable width that reaches its maximum width in the northern part of the Amba Dongar village, where mining operations for fluorite are in progress. Topographically sovites are 
at higher elevations forming a chain of hills around the central depression. From its contact with carbonatite breccia the first few feet of the outcrop comprises coarse sovite passing into medium-grained sovite, which is observed only in the western part of the ring dike. Vertical banding is conspicuous in some parts of the ring dike, accentuated by the presence of apatite, barite, and martite while sometimes it is marked by the presence of orthoclase and some streaks of aegirinefeldspar rock. Frequently jasper veins are seen standing out prominently on weathered surfaces. Faces cut open during mining operations in the northern part of the ring dike provide excellent illustrations of minor structural disturbances such as faulting and fracturing. In some portions a very peculiar type of structure was noticed. The rock becomes highly 'vesicular' and light in nature. During silicification of sovite this light rock was also silicified but it still retained its original form, which now resembles a 'honey comb' structure.

Besides the major rim of the central complex there are isolated plugs of sovite outside the ring within sandstone.

Sovite has caught up various xenoliths which vary in size from $2 \mathrm{~cm}$ to $10 \mathrm{~m}$. or even more sometimes. The largest xenolith (fenitized sandstone) exposed during mining measures $200 \mathrm{~m} \times 40 \mathrm{~m}$. All the xenoliths are fenitized.

\section{Ankeritic carbonatite}

Circular and oblong plugs of ankeritic carbonatite intrude sovite with a sharp contact which is clearly visible even on weathered ground, since the ankeritic carbonatite forms dark brown soil rich in iron oxide. Where the rock is rich in manganese the soil cap is black in colour. Weathering appears to be more effective in the valleys where the outcrops of ankeritic carbonatite are mantled by dark brown to black soil. The ankeritic carbonatite has caught up the xenoliths of sovite and fenites. In places the potash fenites are so much shattered and veined by ankeritic carbonatite that only the patches of feldspar (pink) are seen surrounded by ankeritic material. All the outcrops of ankeritic carbonatite are highly radioactive.

\section{Sideritic carbonatite}

These veins, black in colour, are restricted to exposures of the ankeritic carbonatite plug southwest of Amba Dongar village. The average thickness of the veins is about $4 \mathrm{~cm}$ and they run for only short distances.

\section{Alvikite}

Numerous dikelets of calcitic carbonatite ranging in width from $3 \mathrm{~cm}$ to $15 \mathrm{~cm}$ are noticed in sovite, fenite, carbonatite breccia and sandstone. In some dikelets calcite crystals along the margin show lineation. Even along thin dikes effects of fenitization on the surrounding sandstone are noticed. A network of alvikites invades sovite and carbonatite breccia at the base of the steep escarpment in the eastern part of the ring dike. The dikelets are quite thin but swell out in some places. The entire area is intensely disturbed by minor doming of surrounding rocks. The details of this interesting area have not yet been reported mainly due to the inaccessibility of the area, the abundance of snakes and the presence of hostile tribals.

From the field evidence collected so far it can be assumed that there are probably two phases of alvikite intrusions.

\section{Silicified carbonatite}

This is the most common rock type associated with fluorite mineralization. Towards the end of the carbonatite activity hydrothermal solutions rich in fluorine and silica 


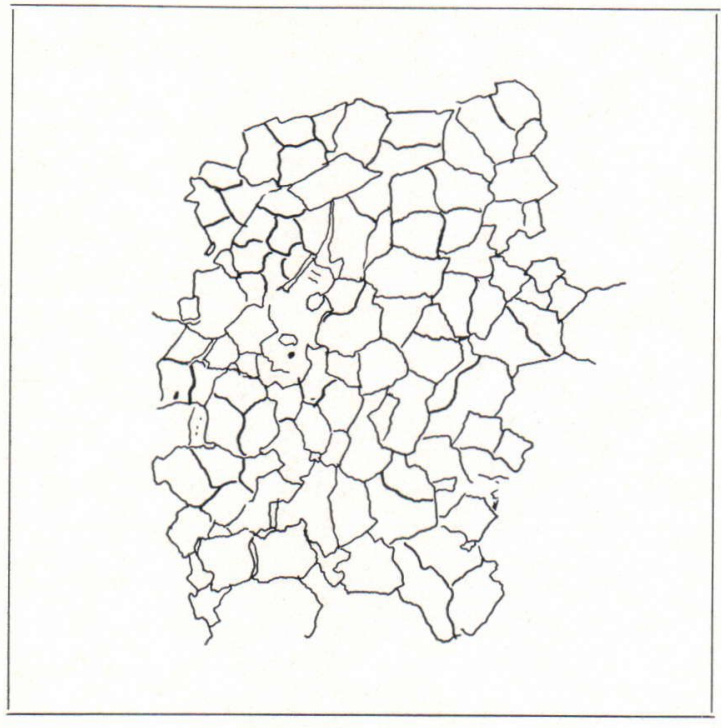

Fig. $4 \mathrm{a}$

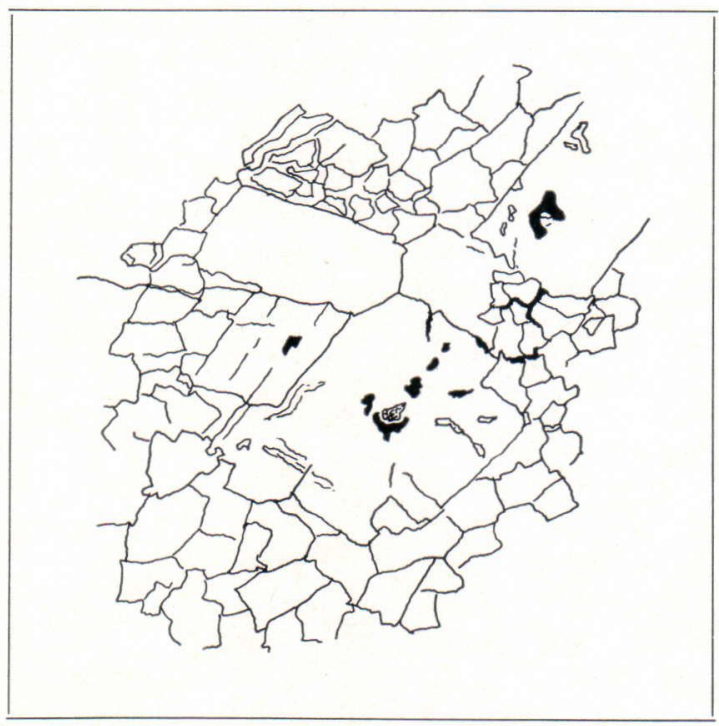

Fig. 4 b

were responsible for replacing sovite towards its outer rim. The outcrops of such rocks are non-uniform in width.

\section{Pegmatitic sovite}

These are very coarse-grained rocks, with calcite crystals averaging 1.5 to $2 \mathrm{~cm}$, in-

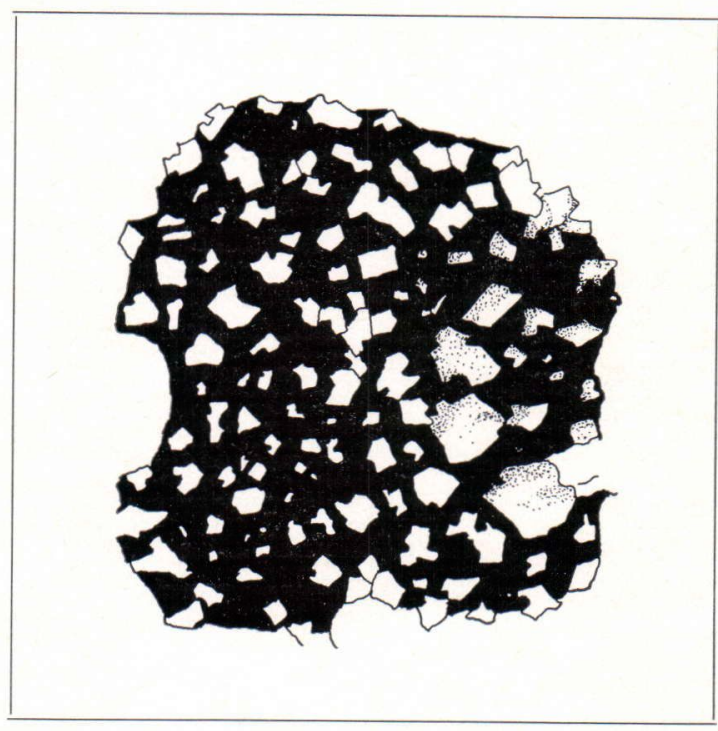

Fig. $4 \mathrm{c}$

Fig. 4. Different types of textures seen in sovite (traced from photomicrographs)
a. fine-grained
b. porphyritic
c. fragmental

vading sovite. The thickness of such veins varies from $1 \mathrm{~cm}$ to $8 \mathrm{~cm}$ and they stand out prominently, as calcite crystals are conspicuous due to their milky white colour.

\section{Petrography}

\section{Sovite}

In a hand specimen, the texture of sovite varies from coarse-grained to extremely finegrained and resembles marble. In thin sections the variation in grain size leads to textures from coarse-grained to fine porphyritic (Fig. 4). In porphyritic varieties earlier formed calcite rhombohedra are set in a matrix of anhedral calcite grains. In coarse-grained sovite large calcite crystals $(1.5 \mathrm{~mm})$ invariably show fused crystal mar- 
gins. Sometimes the large phenocrysts of calcite are rimmed by hematitic material while in some rocks oxidized ankerite and iron oxide form the base for anhedral calcite crystals. Inclusions of iron oxide are often arranged along the cleavage planes or they line the crystal margins. Fine-grained sovite (calcite: $0.15 \mathrm{~mm}$ ) normally shows mosaic texture and calcite grains are devoid of cleavage.

Sovite is composed essentially of calcite, which is non-fluorescent with abundant inclusions of fine material brown in colour. Accessory minerals are: apatite, fluorite, barite, ankerite, phlogopite, pyrochlore, magnetite and bastnaesite (rare).

Apatite $(0.75$ to $1.0 \mathrm{~mm})$ occurs in three crystal habits: ovoid grains, prismatic needles and hexagonal stubby crystals (Fig. 5). It is often replaced on rims by calcite and has inclusions of magnetite. Fluid inclusions, seen at high magnification, are often rounded or oblong. Some rocks show a notable concentration of apatite in the form of clusters and streaks.

Barite is another ubiquitous mineral along with apatite, having crystallized at early magmatic and late hydrothermal stages. Early magmatic grains $(0.34$ to $1.1 \mathrm{~mm})$ are often corroded or replaced by calcite. Sometimes the concentration of barite is high enough to warrant the rock being called barite-sovite. Hydrothermal barite is associated with fluorite veins.

Magnetite ( 0.3 to $0.47 \mathrm{~mm}$ ), often martitized, is skeletal, octahedral and corroded by calcite. Ilmenite is sporadic.

Phlogopite forms small flakes and sometimes occurs in segregated patches. It shows pleochroism from colourless $(\mathrm{X})$ to brownish yellow (Z).

Pyrochlore occurs as small crystals ( 0.07 to $0.17 \mathrm{~mm})$, cubes $(0.12$ to $0.35 \mathrm{~mm}$ ) or rounded grains, cinnamon or yellow in colour, having a dark core and light margins (Fig. 6). Some- times pyrochlore has developed along the crystal margins of calcite while occasionally it clusters around magnetite grains. The majority of the grains show embayment by calcite.

Bastnaesite is extremely rare and occurs as radiating needles.

Some examples of the mineral composition of sovite are given in Table 1 .

\section{Alvikites}

These are medium- to fine-grained rocks, some of them showing tabular texture. The common accessory mineral is apatite which in some rocks occurs as accicular needles. Pyrochlore is rare, while magnetite occurs in good proportion in some specimens.

\section{Ankeritic carbonatite}

These are dark brown coloured, mediumto fine-grained rocks with high radioactivity. Sometimes, due to high magnetite content, they are heavy, resembling iron ore. The rocks are mainly composed of ankerite, which in majority of cases is oxidized to hematite while still preserving the original form of ankerite. Apatite and monazite are seen in minor amounts, while barite and fluorite occur in high proportions. Thorite was no-

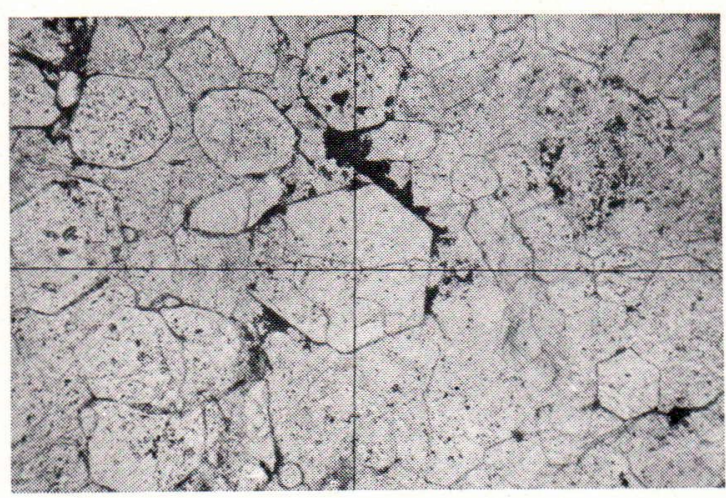

Fig. 5. Apatite in sovite showing different crystal habits (plane polarized light. x160) 


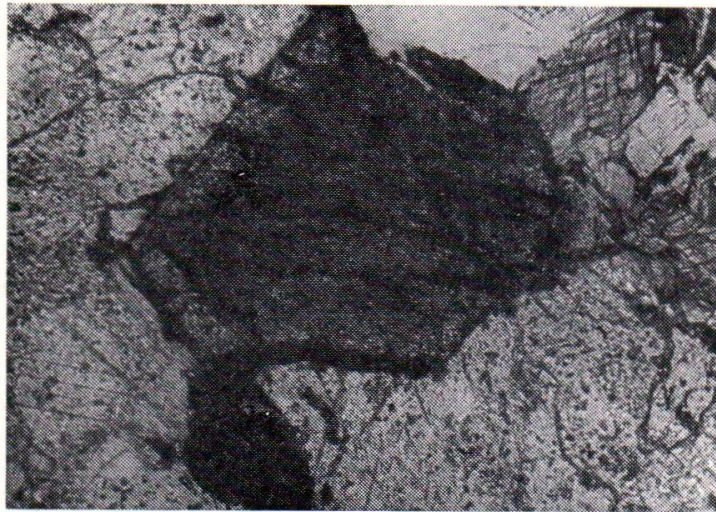

Fig. 6. Pyrochlore in sovite (plane polarized light $\mathrm{x} 270$ )

ticed in one thin section only. The veins of ankeritic carbonatite in sovite are ochreous red in colour and normally without accessory minerals.

\section{Sideritic carbonatite}

These are dark brown to black coloured rocks and sometimes opaque in thin sections. High manganese is characteristic but no manganese mineral could be identified.

A large quantity of iron oxide, cherry red in colour, occurs as fracture filling material in fluorite mineralized zones. The origin of this material is not yet understood but it does not seem to be a product of weathering. Fluorite crystals are normally found embedded in such pockets.

\section{Chemistry}

The detailed geochemistry of different carbonatite units is under study. The major and trace elements (Tables 2 and 3) in sovite (ring dike) and ankeritic carbonatite (plugs) are discussed below.

Amba Dongar sovites are characterised by a low content of $\mathrm{Mg}$, and the small amount that is present is accommodated in the calcite lattice. No exsolved lamellae of dolomite were detected in any sovite on staining. The crystallization differentiation is well observed in Amba Dongar carbonatites with the order of crystallization: sovite - ankeritic carbonatite - sideritic carbonatite indicating an increase in pressure during differentiation. The absence of the dolomite phase and the large proportion of ankeritic carbonatite could be due to the initial high iron content of the melt.

Both iron and manganese show abundances increasing from early sovite to youngest sideritic carbonatite. Cobalt (2 ppm to 39 ppm), nickel (1 ppm to $6 \mathrm{ppm}$ ) and chromium (7 ppm to $33 \mathrm{ppm}$ ) are present only in ankeritic carbonatite and totally absent from sovite. Phosphorus is rather unevenly distributed and the highest concentrations reached in both sovite and ankeritic carbonatite are more than 3 per cent.

Barium is abundant and exceeds strontium. Barite in Amba Dongar carbonatites shows

Table 1. Mineral composition of sovite in volume $\%$.

\begin{tabular}{|c|c|c|c|c|c|c|c|c|c|}
\hline Sp. Nos. & 185 & 193 & 203 & 152 & 121 & 128 & 149 & 198 & 187 \\
\hline Calcite & 74.3 & 78.5 & $85.0 *$ & 80.0 & 66.0 & 76.0 & 83.0 & 79.3 & 67.0 \\
\hline Barite & 4.5 & - & 7.5 & 7.0 & 9.0 & 1.6 & 1.0 & 1.4 & 6.7 \\
\hline Apatite & 5.4 & 15.3 & 6.6 & 12.0 & 13.0 & - & tr. & 13.0 & 9.0 \\
\hline Phlogopite & 9.0 & - & - & - & - & - & - & - & 3.0 \\
\hline Hematite & 4.4 & - & - & 1.0 & 1.0 & 18.0 & 10.0 & 4.4 & 3.6 \\
\hline Magnetite & 2.5 & 4.6 & - & - & 11.0 & - & 6.0 & 1.3 & 8.8 \\
\hline Pyrochlore & - & 1.6 & - & - & - & 4.4 & 0.3 & 0.6 & 1.7 \\
\hline Fluorite & - & - & 1.0 & - & - & - & - & - & - \\
\hline
\end{tabular}

* contains $12.0 \%$ phenocrysts of calcite

All are surface samples from different parts of ring dike. 
Table 2. Major element analyses of carbonatites.

\begin{tabular}{|c|c|c|c|c|c|c|c|c|c|c|c|}
\hline Sp. No. & 1 & 2 & 3 & 4 & 5 & 6 & 7 & 8 & 9 & 10 & 11 \\
\hline $\mathrm{SiO}_{2}$ & 1.84 & 2.00 & 3.94 & 41.88 & 0.36 & 13.13 & 1.20 & 40.02 & n.a. & n.a. & n.a. \\
\hline $\mathrm{TiO}_{2}$ & 0.20 & 0.19 & 0.29 & 0.38 & 0.80 & 0.28 & 0.70 & 0.10 & 0.20 & 0.20 & 1.20 \\
\hline $\mathrm{Al}_{2} \mathrm{O}_{3}$ & 1.77 & 1.25 & 2.79 & 6.00 & n.d. & n.d. & n.d. & 0.43 & n.a. & n.a. & n.a. \\
\hline $\mathrm{Fe}_{2} \mathrm{O}_{3}$ & 2.86 & 2.35 & 3.47 & 8.18 & 19.71 & 10.20 & 17.15 & 9.72 & 10.75 & 8.47 & 45.00 \\
\hline $\mathrm{FeO}$ & 0.16 & 0.28 & 0.64 & 1.40 & n.d. & n.d. & n.d. & n.d. & n.d. & n.d. & n.d. \\
\hline $\mathrm{MnO}$ & 0.47 & 0.15 & 0.35 & 0.31 & 4.50 & 2.46 & 0.67 & 1.58 & 1.92 & 1.14 & 5.00 \\
\hline $\mathrm{MgO}$ & 2.25 & 2.00 & 3.75 & 3.48 & 7.50 & 1.25 & 1.25 & 4.60 & 6.72 & 12.48 & 7.50 \\
\hline $\mathrm{CaO}$ & 49.68 & 50.03 & 46.15 & 16.90 & 35.61 & 38.85 & 43.40 & 22.50 & 37.75 & 35.03 & 15.41 \\
\hline $\mathrm{Na}_{2} \mathrm{O}$ & 0.16 & 0.10 & 0.14 & 6.00 & 0.15 & 1.18 & 0.23 & 0.11 & n.d. & n.d. & n.d. \\
\hline $\mathrm{K}_{2} \mathrm{O}$ & 0.04 & 0.08 & 0.70 & 2.75 & 0.04 & 0.02 & 0.03 & 0.06 & n.d. & n.d. & n.d. \\
\hline $\mathrm{P}_{2} \mathrm{O}_{5}$ & 1.14 & 1.70 & 0.71 & 1.00 & 1.88 & 0.39 & 0.09 & tr. & 0.20 & 0.31 & 0.68 \\
\hline $\mathrm{CO}_{2}$ & 39.00 & 39.60 & 36.20 & 9.00 & 28.16 & 32.06 & 35.10 & 20.00 & 38.00 & 36.50 & 23.50 \\
\hline$\underline{\mathrm{H}_{2} \mathrm{O} \pm}$ & 1.08 & 1.24 & 1.12 & 1.75 & 1.40 & 0.78 & 0.44 & 1.50 & 2.70 & 2.40 & \\
\hline Total & 100.65 & 100.97 & 100.25 & 99.03 & 100.11 & 99.60 & 100.26 & 100.62 & 98.22 & 96.53 & 97.09 \\
\hline
\end{tabular}

All analyses were carried out following the method of Shapiro and Brannock (1962).

Analyst: S. G. Viladkar

Location:

Sp. No. 1, 2, 3

4
5
6,7
8
9,10
11

sovite from ring dyke

xenolith of aegirine-phlogopite sovite within ring dyke of sovite

ankeritic carbonatite from plug, SW of Amba Dongar (ankerite is oxidized)

sovite with oxidized ankeritic groundmass

silicified carbonatite

ankeritic vein in sovite

sideritic carbonatite vein in ankeritic carbonatite plug southwest of Amba Dongar

a long range of crystallization from early magmatic to late hydrothermal. The large quantity of barite crystallizing in Amba Dongar carbonatites could be attributed to a high concentration of sulphur coupled with prevailing oxidizing conditions and low temperatures. Sethna and Viladkar (1977) have given the temperature of crystallization for Amba Dongar carbonatites as from $250^{\circ}$ to $500^{\circ} \mathrm{C}$. The concentration of strontium in sovite and ankeritic carbonatite varies from $1117 \mathrm{ppm}$ to $3400 \mathrm{ppm}$ (average $2394 \mathrm{ppm}$ ) and $1400 \mathrm{ppm}$ to $5250 \mathrm{ppm}$ (average 2723 ppm) respectively.

The niobium concentration in sovite and ankeritic carbonatite varies from $50 \mathrm{ppm}$ to $1636 \mathrm{ppm}$. The highest concentration (1636 ppm) in sovite (sp. no. 192) is undoubtedly due to the abundant pyrochlore present in this rock.

Cerium and lanthanum show distinct enrichment from early sovite to late ankeritic carbonatite, which contains well over $3.0 \%$
$\mathrm{Ce}+\mathrm{La} . \mathrm{Ce}+\mathrm{La}$ predominate over $\mathrm{Y}$ and the average ratios $(\mathrm{Ce}+\mathrm{La}) / \mathrm{Y}$ for sovite and ankeritic carbonatite are 43 and 104 respectively. The high concentration of $\mathrm{Ce}$ and $\mathrm{La}$ in ankeritic carbonatite may be due to the presence of monazite, while in sovite these elements are mainly dispersed in calcite (in sovite bastnaesite occurs in traces). Apart from $\mathrm{Ce}$ and $\mathrm{La}$, five samples of carbonatites were analysed for $\mathrm{Eu}$, which varies from 5 ppm to $50 \mathrm{ppm}$.

\section{Fenitization}

The details of fenitization of Bagh sandstone have already been described by Deans et al. $(1972,1973)$ and Sukheswala and Viladkar (in press). Two distinct trends of fenitization are seen in Amba Dongar: earlier soda fenitization, wherein the introduction of both $\mathrm{Na}$ and $\mathrm{K}$ (but $\mathrm{Na}>\mathrm{K}$ ) led to the formation of fenites rich in aegirine-augite aegirine, orthoclase and albite; later potash fenitiza- 
Table 3. Trace element contents of Amba Dongar carbonatites in ppm.

\begin{tabular}{|c|c|c|c|c|c|c|c|c|c|c|c|}
\hline Sp. No. & $\mathrm{Ba}$ & $\mathrm{Sr}$ & $\mathrm{Zr}$ & $\mathrm{Nb}$ & $\mathrm{Zn}$ & $\mathrm{Ce}$ & $\mathrm{La}$ & $\mathrm{Y}$ & Th & $\mathrm{Mn}$ & $\mathrm{P}$ \\
\hline \multicolumn{12}{|l|}{ Sovite } \\
\hline 16 & 1500 & 4500 & n.d. & 270 & n.a. & 900 & 250 & 40 & n.d. & 1200 & 760 \\
\hline 185 & 24300 & 3400 & n.a. & 350 & n.a. & 3600 & 2420 & 49 & n.a. & 2730 & 7100 \\
\hline 295 & 18100 & 3000 & n.a. & 50 & n.a. & 2320 & 1240 & 70 & n.a. & 2200 & 6900 \\
\hline 2 & 10100 & 2000 & n.a. & 250 & n.a. & 2700 & 800 & 130 & n.a. & 3700 & 4700 \\
\hline 13 & n.a. & 1351 & 153 & 948 & 424 & 7329 & 6593 & 159 & 222 & 7300 & 7900 \\
\hline 15 & n.a. & 2206 & 177 & 319 & 139 & 1185 & 130 & 122 & 118 & 3600 & 33600 \\
\hline 19 & n.a. & 2708 & 155 & 554 & 98 & 516 & 80 & 45 & 77 & 2300 & 9300 \\
\hline 60 & n.a. & 2825 & 140 & 271 & 234 & 1227 & 358 & 83 & 17 & 2300 & 31000 \\
\hline 130 & n.a. & 1117 & 60 & 399 & 124 & 2891 & 1143 & 63 & 32 & 7200 & 5700 \\
\hline 147 & n.a. & 2313 & 101 & 202 & 306 & 1934 & 552 & 107 & 195 & 9200 & 11300 \\
\hline 149 & n.a. & 1932 & 101 & 47 & 131 & 1467 & 332 & 71 & 98 & 3700 & 12500 \\
\hline 192 & n.a. & 1374 & 90 & 1636 & 100 & 1055 & 336 & 19 & 80 & 1400 & 14100 \\
\hline \multicolumn{12}{|c|}{ Ankeritic carbonatite } \\
\hline 3 & n.a. & 2105 & 509 & 86 & 1215 & 9550 & 3761 & 190 & 248 & 5000 & 13600 \\
\hline 5 & n.a. & 1636 & 541 & 977 & 237 & 2000 & 385 & 200 & 249 & 5800 & 32500 \\
\hline 6 & n.a. & 3190 & 159 & 244 & 44 & 453 & 121 & 24 & 3 & 1000 & 8500 \\
\hline 646 & 8400 & 3100 & n.a. & 500 & n.a. & 13260 & 12000 & n.a. & n.a. & 2290 & 8700 \\
\hline 11 & n.a. & 3100 & n.a. & 500 & n.a. & 22400 & 15100 & 190 & n.a. & 34900 & 4000 \\
\hline 29 & n.a. & 5250 & 450 & 450 & n.a. & 13960 & 17900 & 90 & n.a. & 19100 & 170 \\
\hline 448 & 8200 & 1400 & n.a. & 250 & n.a. & 870 & 740 & 34 & n.a. & 4180 & n.a. \\
\hline 59 & 9000 & 2000 & n.a. & 570 & n.a. & 3000 & 1450 & 150 & n.a. & 5200 & 400 \\
\hline \multicolumn{12}{|c|}{ Carbonatite breccia } \\
\hline 49 & n.a. & 1369 & 69 & 141 & 233 & 1111 & 351 & 42 & 8 & 2200 & 7900 \\
\hline 24 & n.a. & 2179 & 137 & 335 & 220 & 1293 & 415 & 120 & 89 & 4700 & 12400 \\
\hline 25 & n.a. & 2383 & 128 & 212 & 222 & 1518 & 370 & 63 & 79 & 5100 & 9200 \\
\hline 34 & n.a. & 2307 & 149 & 396 & 406 & 1991 & 1237 & 99 & 167 & 4800 & 7200 \\
\hline
\end{tabular}

n.a. not analyzed

n.d. not detected

tion was superimposed on earlier soda fenites and gave rise to pure potash fenites - orthoclase rocks - with relics of aegirine-augite and aegirine. Mild nephelinization has also been observed in one of the outcrops of fenite, occurring as xenoliths in sovite. The syenitefenite from the marginal part of the outcrop shows typical igneous texture but the samples collected from the centre of the outcrop still show original sandstone features with development of aegirine-augite and albite.

The fenitization of nephelinites is briefly described here and the details will be given later elsewhere. The samples for such study were selected from the xenoliths of nephelinite in sovite which are exposed on road cuttings and in the mine adit, and also from the plugs of nephelinites situated not very far from sovite outcrops. The petrographic study shows that the nephelinites were affected by the fenitizing solutions from the sovite magma. Nepheline is converted to fibrous hydromuscovite or is completely replaced by calcite retaining the original form. Orthoclase develops as poikilitic plates. Melanite shows partial replacement by sphene which is normally promoted along the cracks in melanite and sometimes is partially replaced by calcite. In places it shows sieve structure and bleaching of the originally dark colour. Aegirine-augite shows two changes: in some rocks it is replaced by wollastonite on the crystal margins, while in others phlogopite seems to have developed.

The effects of fenitization are more pronounced on xenoliths of nephelinites in sovite.

\section{Travertine}

Travertine forms thick deposits in all major valleys bordering the Amba Dongar dome. Chemically they are similar to car- 
bonatites with elevated $\mathrm{Na}_{2} \mathrm{O}$. The concentrations of other elements are: $\operatorname{Sr}(2270 \mathrm{ppm})$, $\mathrm{Ba}(432 \mathrm{ppm}) \mathrm{Nb}(<5 \mathrm{ppm})$, Ce $(64 \mathrm{ppm})$, La $(<5 \mathrm{ppm})$. (work in progress).

\section{Mode of emplacement}

The carbonatite-alkalic complex of Amba Dongar is situated on the northwestern periphery of the Deccan Trap province, which is underlain by Bagh sediments and Dharwar metamorphics. The metamorphics are exposed in the northern periphery of the Chhota Udaipur carbonatite-alkalic district forming elongated hills striking NW-SE. The eroded and carved basins of the Pre-Cambrian metamorphics provided favourable places for the deposition of Bagh sediments during the Cretaceous period. Towards the late Cretaceous period the Baghs were covered by the stupendous activity of flood basalts designated in Indian geology as Deccan Traps. The lavas erupted mainly through fissures with sporadic central type eruptions.

The Amba Dongar complex is situated in the rift zone of Narmada valley which is regarded as an 'ancient plane of weakness' along which tectonic activities have occurred (West, 1962). According to Tandon and Choudhury (1970), epicentres of many earthquake shocks are aligned approximately parallel to the Narmada-Son lineament (Fig. 1). Mishra (1977) presumes the extension of this lineament to be to the Murray Ridge in the west and to the eastern syntaxial bend in the east connecting this structure with the worldwide rift system.

The Amba Dongar complex lies in a structurally disturbed zone. It is a typical subvolcanic diatreme formed by the process of fluidization which was responsible for the emplacement of a plug of carbonatite breccia accompanied by the initial doming of the Baghs and Deccan basalts. In the second phase of activity the roof of this volcano collapsed and the carbonatite melt was pushed up along a ring fault resulting in the emplacement of the sovite ring dike. Major doming occurred during this period. Sovite was then intruded by the later differentiate ankeritic carbonatite. The end of carbonatite activity is marked by the deposition of large fluorite deposits with associated quartz, galena, barite, pyrite and chalcopyrite.

Geological field work for the past few years has established that even after the emplacement of carbonatite the volcanic activity did not cease but from the same conduit multiple injections of basalt invaded the original core of carbonatite breccia leaving behind only a collar of it around the newly formed core of basalt. A number of dolerite dikes have been observed in $1 \mathrm{~km}$ periphery of this core.

It may be concluded that the Amba Dongar carbonatite-alkalic complex represents a typical high level sub-volcanic diatreme, which has preserved many of the original characteristics. Similar to Chitwa Island in Malawi (Garson, 1966), the differentiation of carbonatite is well documented in Amba Dongar by successive intrusions of soviteankeritic carbonatite - sideritic carbonatite. Carbonatites are rich in apatite and barite, and apatite forms segregated pools and streaks in sovite. Ankeritic carbonatites are exceptionally enriched in Ce and La.

Acknowledgements - I am grateful to Dr. Heikki Vartiainen, Senior Geologist of Rautaruukki Oy, Finland who carefully read the manuscript and made invaluable suggestions for its improvement. I am also highly thankful to Professors R. N. Sukheswala and S. F. Sethna for their critical comments, to Dr. M. Sankar Das, Head, Analytical Division, Bhabha Atomic Research Centre, Bombay and Mr. G. P. Venkateswaran, Department of Natural Resources, New Brunswick, Canada for the trace element analyses of carbonatites by Neutron Activation method and XRF. 


\section{References}

Deans, T. and Powell, J. L. (1968) Trace elements and strontium isotopes in carbonatites, fluorites and limestones from India and Pakistan. Nature 218. $750-752$.

Deans, T., Sukheswala, R. N., Sethna, S. F. and Viladkar, S. G. (1972) Metasomatic feldspar rocks (potash fenites) associated with the fluorite deposits and carbonatites of Amba Dongar, Gujarat, India. Trans. Inst. Min. Metall. Sec. B. 81. $1-9$.

- (1973) Discussions and Contributions. Trans. Inst. Min. Metall. Sec. B. 82. 33-39.

Garson, M. S. (1966) Carbonatites in Malawi. In: Carbonatites Eds. O. F. Tuttle and J. Gittins. Interscience publishers. New York. 33-71.

Mishra, D. C. (1977) Possible extensions of the Narmada-Son lineament towards Murray Ridge (Arabian Sea) and the Eeastern syntaxial bend of the Himalayas. Earth. Pla. Sci. Lett. 36. $301-308$.

Mitchell, R. H. and Krause, H. R. (1975) Sulphur isotope geochemistry of carbonatites. Geochim. Cosmochim. Acta. 39. 1505-1513.

Sethna, S. F. (1971) A note on the trace element contents of carbonatites of Amba Dongar and surrounding areas, Chhota Udaipur, Jour. Geol. Soc. India 12. $311-317$.

Sethna, S. F. and Viladkar, S. G. (1977) An estimation of temperature of intrusion of Indian carbonatites using calcite-dolomite geothermometry. Jour. Geol. Soc. India 18. 275-280.

Shapiro, L. and Brannock, W. W. (1962) Rapid analysis of silicate rocks. U. S. Geol. Surv. Bull. 1144-A. 1-56.

Sukheswala, R. N. and Avasia, R. K. (1971) Carbonatite-alkalic complex of Panwad-Kawant, Gujarat and its bearing on the structural char- acteristics of the area. Bull. Volcanol. Tome XXXV-3. 564-578.

Sukheswala, R. N., Avasia, R. K. and Viladkar, $S$. G. Deccan basalts associated with carbonatite volcanism, Chhota Udaipur, Gujarat, India. (in press).

Sukheswala, R. N. and Udas, G. R. (1963) Note on the carbonatite of Amba Dongar (Gujarat State) and its economic potentialities. Sci. Cult. 29. $563-568$.

- (1964) The carbonatite of Amba Dongar, India, Some structural considerations. XXII Inter. Geol. Congr. India VII. $1-13$.

- (1967) Fluorspar mineralization related to carbonatite-alkalic complex at Amba Dongar, Gujarat State. Curr. Sci 36. 14-16.

Sukheswala, R. N. and Viladkar, S. G. (1978) Carbonatites of India. Proc. 1st Inter. Symp. on carbonatites, Brazil. pp 277-293.

- Fenitized sandstones in Amba Dongar, Gujarat, India. (in press).

Tandon, A. N. and Choudhury, H. M. (1970) Seismometric study of the Koyna earthquake of December 11, 1967. Indian J. Power River Valley Dev. Symp. on Koyna Earthquake.

Viladkar, S. G. (1972) Carbonatite-alkalic complex of Amba Dongar, Chhota Udaipur, Gujarat, Unpublished $\mathrm{Ph}$. D. thesis, Bombay University.

West, W. D. (1962) The line of Narmada-Son valley. Curr. Sci. 31. p 143.

Wyllie, P. J. (1966) Experimental studies of carbonatite problems: The origin and differentiation of carbonatite magmas. In Carbonatites Eds. O. F. Tuttle and J. Gittins. Interscience Publishers. New York. 311-352.

Manuscript received, June 9, 1980 